\title{
Hegemony or Hidden Transcripts?: Aboriginal Writings from Lake Condah, 1876-1907
}

\section{Penny van Toorn}

\section{Sutton vs Stahle}

In the winter of 1876 , Robert Sutton, a young Kerrupjmara resident of Lake Condah Mission Station in south-western Victoria, took the unprecedented step of issuing a summons against the station superintendent, Reverend John Heinrich Stahle. He charged Reverend Stahle with assault. A shocked and outraged Stahle duly appeared before the local magistrate. The magistrate dismissed the charge and severely reprimanded Sutton and his two Aboriginal witnesses. He warned them that if they ever told a similar story again they would be put in the lock up. ${ }^{1}$ The magistrate's message was clear: although Stahle had no legal right to use physical violence against the Aboriginal people in his care, should he happen to do so, the victims were not to bring the matter to public attention. By threatening to lock Sutton up for calling violence by its name, the magistrate was not only pushing colonialism's coerciveness out of sight, he was issuing a clear message to Robert Sutton and his people: 'you must behave as though your are satisfied with your lot, or you will be punished'.

What we see in the magistrate's orders is the drawing of a line between what Yale political scientist James C. Scott has called 'hidden and public transcripts' - that which can safely be said publicly - and that which must remain concealed. ${ }^{2}$ In Weapons of the Weak (1985) and Domination and the Arts of Resistance (1990), Scott examines what he describes as 'the fugitive political conduct of subordinate groups' - those covert, indirect modes of physical and ideological dissidence 
that dare not speak their own name. ${ }^{3}$ These hidden forms of resistance pose a challenge to some major tenets developed within Marxist theory. Scott argues that followers of Gramsci in particular have tended to overestimate the effectiveness of hegemonic control because they have looked only at public transcripts, leaving hidden transcripts - that is, concealed and disguised expressions of resistance-out of account.

Traditional understandings of hegemony, Scott argues, have failed to consider two possibilities. The first possibility is that powerless groups, far from being unable to imagine political change:

have learned to clothe their resistance in ritualisms of subordination that serve both to disguise their purposes and to provide them with a ready route of retreat that may soften the consequences of possible failure. ${ }^{4}$

The day-to-day survival of powerless peoples may depend upon their ability to feign willing consent to their own subordination. This pretence involves observing the boundary between the public and hidden transcripts. To violate that boundary would be to commit an open act of insubordination, a risk-laden luxury that very vulnerable groups are seldom able to afford, especially if they are living within total institutions such as slave plantations or Aboriginal reserves.

The second possibility overlooked by theorists of hegemony is that dominant groups have their own reasons for concealing resistance to their ideological leadership. As subaltern peoples tactically hide their contempt for the powerful, the latter may hide their knowledge of being defied and despised, and may concomitantly hide the degree to which they must use physical coercion to preserve their position of dominance.

Powerful and powerless alike are thus bound up in a conspiracy of silence about physical oppression and resistance. Both act out a public performance of control and subordination. This principle is neatly encapsulated in an old Ethiopian proverb: 'when the great lord passes, the wise peasant bows deeply, and silently farts'. ${ }^{5}$ Here, not only does the peasant's expression of contempt remain anonymous, inaudible, and 
unprovable, the great lord also preserves his dignity by pretending everything is sweet. The peasant's deep bow and the lord's serene bearing are both part of a performance of hegemonic order; the foul smell is a protest expunged, a protest without trace, as though it never happened. Scott's approach is not without problems of its own, but it does broach an important question: if hegemonic control is invariably accompanied by at least a threat of physical force, how is it possible to gauge the degree to which a group may have been ideologically manoeuvred into genuine, spontaneous submission, as distinct from being physically coerced or threatened into a pretence of submission?

\section{Strategic performances}

These questions are especially pertinent in postcolonial contexts, where the Eurocentric biases of Gramsci's 'hegemony', Althusser's 'ideology', and the Frankfurt school's 'false consciousness' are now becoming apparent. As During has pointed out, these theorists assume 'that both sides are citizens of a single state and work within a shared cultural horizon', which is clearly not the case under colonialism or in the postcolonial world. ${ }^{6}$ Gramsci's theory of hegemony, for example, was based on a distinction between civil society, which promulgates an ideological predisposition to consent and conformity, and the state, which insures discipline through direct rule and physical coercion. Ranajit Guha has pointed to the Eurocentricity of this model, suggesting that the colonial state is fundamentally different from the metropolitan bourgeois state which established it. Guha argues that:

The difference consisted in the fact that the metropolitan state was hegemonic in character with its claim to dominance based on a power relation in which the moment of persuasion outweighed that of coercion, whereas the colonial state was non-hegemonic with persuasion outweighed by coercion in its structure of dominance. We have defined the character of the colonial state therefore as a dominance without hegemony ... For there can be no colonialism without coercion, no subjection of an entire people in their own homeland by foreigners without the explicit use of force. ${ }^{7}$ 
Guha's argument is grounded in the history of the Indian subcontinent, which differs in several respects from that of Australia. In Australia, there were two contrasting orders of persuasion and dominance. In areas where free settlers were numerically and economically dominant, and where colonists did not rely on Indigenous knowledge or modes of production, the Australian colonies resembled the British bourgeois state where hegemony outweighed coercion. Yet Aboriginal people (and convicts in the early years) lived under direct rule and physical coercion on reserves and missions, in prisons and children's homes, and on pastoral properties in some regions. In these institutions, coercion clearly outweighed ideological controls.

On Aboriginal reserves and missions, civil and state spheres were rolled up into a single institution where ideological apparatuses such as school and church were combined with physically coercive state apparatuses such as gaol, children's dormitory and forced labour camp. Many factors militated against overt Aboriginal protests. Oppressive as they were, the reserves were viewed by many Aborigines as their only place of asylum and/or their only option for staying on or near their traditional country. Individuals who complained could be exiled to distant reserves far from kin and homeland. A sustained chorus of Aboriginal complaints could lead to closure of the reserve altogether, and thus the loss of the whole group's traditional or adopted home.

Reserve superintendents too had their reasons to pretend the Aboriginal residents were happy. The reserves were funded by government and church money on the understanding that they provided protection, schooling, religious teaching, and other forms of 'improvement' for Aborigines. At Lake Condah, Reverend Stahle's salary was paid by the Board for the Protection of the Aborigines which was in turn accountable to the government and to taxpayers. Lake Condah mission station also received some funding from the Church of England Mission Society. To protect his own position, Stahle had to pretend his charges were enjoying his protection. Aborigines and mission superintendents thus entered into a strange collusion: each had their reasons for engaging in a public performance of hegemonic order. 
In Victoria during the later decades of the nineteenth century, reserve and mission managers and other government officials generated public transcripts typical of those produced by powerful groups. They were discursive performances that affirmed, naturalised and justified their power over Aboriginal people. For public view, these administrators painted flattering portraits of themselves and the reserve system, portraits that concealed or euphemised 'the dirty linen' of the white man's rule'.

These pretences of benevolence made it possible for Aboriginal people, in their own public transcripts, to make certain kinds of modest claims on their self-proclaimed 'benefactors'. Without raising fears of sedition, or fundamentally challenging protectionist policy, Aboriginal people could request additional food rations, better housing, and other incremental improvements to their living conditions. Much of their correspondence with government officials, and their testimony in official inquiries, was of this non-threatening kind. As such it typifies the public transcripts of powerless peoples. For the most part, the public transcripts of Aboriginal reserve and mission residents were discursive performances of subordination, not manifestations of ideological or cultural assimilation. Complaints and requests were usually made politely and deferentially, and were signed with the conventional formula, 'your most obedient and humble servant'-a poignant form of words given that they were forced to live, quite literally, in servitude.

This formulaic, deferential language worked to camouflage bitter feelings that could not be expressed openly. The camouflage had its cost, however: the Aborigines' deference appeared to hail white officials as superiors, and to ratify white domination. Yet knowing they were likely to be punished for anything resembling open rebellion, the majority of Aboriginal residents on the Victorian reserves stifled overt expressions of anger and resentment. Sometimes for years at a time, they refrained from all but the most covert and oblique modes of resistance. To do otherwise was to risk being beaten, deprived of food and clothing, exiled to distant stations and separated from their families.

Yet from time to time, these performances of paternalistic 
care and submissive acquiescence would suddenly collapse into open expressions of mutual contempt and hostility. While anger and racial hatred periodically disrupted colonialist public discourses of protection and improvement, Aborigines likewise periodically dropped all pretence of gratitude, obedience, and equanimity, and protested against actions of individual reserve managers and/or oppressive policies formulated by the Protection Board.

\section{Doublespeak}

If dissent is kept entirely hidden within a tightly knit group, it is obviously not accessible to present knowledge via the written archive, nor is it guaranteed to be preserved in oral memory. One can therefore only guess at the total extent of Aboriginal people's hidden transcripts. Given the elusiveness of hidden transcripts, one may question how is it known that they circulated on a continuous basis at Lake Condah. Why, for instance, are public protestations such as Robert Sutton's legal action against Stahle viewed as signs of chronic resentment and resistance, rather than as mere flashes of anger in an otherwise peaceful existence?

The answer to this question is two-fold. First, when open dissent breaks out, it does not spring out of nowhere. Robert Sutton's legal action against Stahle could not have been mounted without some degree of preliminary discussion, advice and preparation. Charging Stahle with assault was thus the culmination of a series of consultations and actions that remained hidden until the moment Stahle received the official summons to appear in court.

Second, the ongoing nature of hidden dissent is suggested by the fact that between times of open protest, the public transcripts of subaltern groups may contain coded, sanitised, oblique expressions of resistance. ${ }^{9}$ These veiled protests may remain entirely hidden from the dominant group, yet as a form of doublespeak they express subaltern people's chronic dissatisfaction. In September 1877, for example, Stahle thrashed two fifteen-year-old boys for alleged sexual misconduct with two teenage girls. One of the boys was John Sutton Jr, younger brother of Robert Sutton who had taken Stahle to court for assault the previous year. The other boy 
was Henry Albert, a member of the Green family who were closely connected to the Suttons. As part of their punishment, Stahle made the boys write letters of confession and apology to Captain Page, head of the Board for the Protection of the Aborigines (BPA). Stahle's aim was to shame the boys by forcing them to expose their actions to official scrutiny, just as Robert Sutton had exposed Stahle's actions in court fifteen months previously. Yet the boys' letters are also readable, against the grain imposed by Stahle, as another allegation of assault. John Sutton Jr in particular says almost as much about Stahle's punishment of the boys as about the boys' actions with the girls. His letter to Page may be read as a complaint disguised as an apology. He describes how Stahle:

called us up to his house and gave each one of us a good whipping and after that sent us to work in the rain, and after we were done working he gave us another good beating. This is all what done to us. ${ }^{10}$

The final words of this letter - 'this is all what done to us'suggest that Stahle's 'good beatings' were felt as a violation by John Sutton Jr. Given his brother's earlier protest against Stahle's use of violence, could John Sutton Jr possibly have believed Stahle's whippings were unequivocally just and good? It is reasonable to assume that like most families dealing with a recurrent problem, the Suttons would have discussed Stahle's behaviour among themselves and with their friends. The boys' accounts of being beaten by Stahle may therefore be read as oblique offshoots of a hidden transcript that had existed at least since the lead-up to Robert Sutton's court case. These letters of confession put Stahle's violent propensities once again on the public record, yet unlike Robert Sutton's, the boys' accusations were made at Stahle's command, and were so camouflaged and ambiguous that no one (including myself) could see them unequivocally as a mode of protest.

\section{The 'Grateful Aborigines' petition}

Subordinate groups may signify acceptance of their position not only by remaining silent, but also by actively proclaiming themselves to be satisfied with their lot. Why can't subaltern 
peoples' expressions of contentment be taken at face value, and read as evidence that potential unrest has been hegemonically controlled? One gauge of a people's power is their ability to speak for themselves, and be seen to do so. When Aboriginal people protested against the degrading conditions under which they were forced to live, the authorities often attributed their protests to the influence of 'interfering whites'. When they expressed their gratitude and contentment, however, the authorities insisted they were speaking freely and spontaneously for themselves. Overt expressions of contentment cannot be taken at face value, not only because powerless people risk punishment if they show dissent, but because their voices may either be drowned out, mediated, or ventriloquised in distorting ways.

In September 1877, the same month as John Sutton Jr and Henry Albert wrote their letters of confession, Stahle recommended to Page that the boys' fathers, John Sutton Sr and Thomas Green, along with Billy Gorrie and Jackie Fraser, be refused work certificates. He alleged that while away shearing the previous year, they had spent their money on alcohol and 'came back to the Mission Station in rags'. ${ }^{11}$ In protest against Stahle's unwillingness to let them go, the men refused to work on the station. Stahle stopped their food and tobacco rations but found the situation so trying that he earnestly requested the Board 'to take steps in the matter'. ${ }^{12}$

Stahle took steps of his own to show the board how disruptive Sutton's group were. He wrote a petition to Captain Page on behalf of nineteen Aboriginal men who, he asserted:

requested me on their own account to write for them to the Board for the Protection of the Aborigines informing them that they are dissatisfied with the conduct the men
Tommy Green
John Sutton
Billy Gorrie and their boys
Henry Albert \& John Sutton Jr. 
I asked the men why they wished me to forward their names and they said that they are desirous to express their thankfulness for that which is done for them by the Board and also to tell them that it is their desire to go on quietly \& steadily to labour on their own home ... [A]s the Aborigines have requested me to forward their names along with the expression of the thankfulness to the Board-I considered it my duty to comply with their wish. I have the honor to be

Sir

Your obedient Servant

J. H. Stahle ${ }^{13}$

After Stahle's signature appear the names of nineteen men, five of whom sign for themselves. The remaining fourteen names, all with identical crosses beside them, are added in Stahle's writing.

Taking this petition at face value, we might read it as proof of the power of hegemony, a confirmation that the majority of Aboriginal residents at Condah consented willingly to their lot. A second possibility is that the document may have originated in the signatories' wish to maintain a pretence of contentment. Stahle had cut off the "troublemakers" food and tobacco rations, and was refusing their requests for certificates to obtain employment outside the station. The nineteen petitioners who declared themselves dissatisfied with the conduct of Sutton's group, and satisfied with Stahle's management, may well have being trying to shield themselves and their families from any blanket disciplinary measures they feared the Board might have been considering. A third possibility is that since fourteen of the nineteen signatures and crosses are in Stahle's writing, they might have been made without the signatories' full knowledge and informed consent. If such was the case, Stahle may be seen as literally writing the public transcript of the Aboriginal signatories, ventriloquising the Lake Condah majority's enunciation of consent to their own subordination.

The 'Aboriginals' Narrative' - a suppressed and hidden transcript At Lake Condah there is evidence to suggest that John Sutton Sr. and his group harboured resentments against Stahle and 
the Protection Board on an ongoing basis over many years. Sometimes their protests alternated between being suppressed from above and deliberately concealed from below. Such was the case with a document known as 'The Aboriginals' Narrative' which contains the story of its own difficult emergence from the hidden to the public realm.

In March 1878, an incident occurred at Lake Condah that angered John Sutton Sr and other senior men on the reserve. Stahle failed to look into the men's allegations that two of the younger men had engaged in sexual misconduct with two young women. Stahle's inaction appeared both to defy Christian morality and to slight one of the senior men's traditional responsibilities as uncle to the young women involved. Remembering perhaps how their own sons had been physically beaten for sexual misconduct, John Sutton Sr and Thomas Green were surprised and angered that Stahle made no move even to reprimand the alleged culprits. When the men were gathered for ration distribution - a humiliating weekly display of the men's impotence and Stahle's powertensions escalated to such a degree that Stahle shut the ration store and sent for the police. Sutton and his group tried on several occasions to notify Board and Church officials of their grievances against Stahle. Their complaints were either blocked or explained away by Stahle. Yet these grievances continued to circulate in the Condah community where they were a powerful focus of resentment against Stahle.

John Sutton Sr and the other men did not forget what had happened. In May 1880, twenty-six months after the incident occurred, they tried to make their complaints known to a visiting church official, but he was hurried away by Stahle. Stahle's attempts to suppress the men's story in fact helped keep it alive. Two months after the church official's visit, in July 188o, John Sutton and his group enlisted the aid of a local white man, Mr. F. Elmore, who wrote down their complaints in detail. The document is headed 'Aboriginals' Narrative' and consists of four closely written foolscap pages. It is signed with crosses by John Sutton, Thomas Green and Billy Gorrie. The men kept this document to themselves for a further four months until November 188o, when they sent it to Captain Page, to whom Stahle was accountable. In total, this set of 
Aboriginal complaints remained hidden for thirty-two months, before finally being exposed to official scrutiny.

Whenever John Sutton Sr and his group enlisted outside help to put their grievances on paper, Stahle ascribed their recalcitrance to 'white interference'. Stahle's position in the middle of a bureaucratic hierarchy was a difficult one. On the station, he could behave autocratically; in relation to his Aboriginal charges, he wielded almost absolute power. On the station he expressed hostile attitudes which others might not have revealed to those they governed, attitudes which a more self-disciplined manager might have kept hidden.

Officially, Stahle's role was to look after the Condah people's day-to-day welfare. Yet since his abrasive managerial style could be construed as a sign of unfitness for the job, he would not have wanted everything that went on at Lake Condah to be known outside the station. Powerful as he was in the closed Condah setting, he occupied a relatively powerless position in the government and church hierarchies. In official communications with superiors, therefore, we often see him choosing his words carefully, and attempting (not always successfully) to respect professionally appropriate principles of discretion. Stahle, in effect, had two sets of public and hidden transcripts, the boundaries of which shifted depending on whether he was speaking up the power hierarchy to those who paid his salary, or speaking down to the Aboriginal people whose lives he controlled. What he could say openly to each audience had often to be hidden from the other.

The problem Stahle faced was keeping these two audiences from speaking to each other. He was safe from criticism from above as long as word of his actions and attitudes remained confined to the station, or was conveyed to the Board solely by himself in carefully chosen terms. Such was not the case, however. As the younger Condah residents learned to read and write, and as the older ones gained support from local whites willing to write on their behalf, Stahle found it increasingly difficult to control the flow of information into and out of Condah station. The technology of writing enabled the Condah Aborigines to communicate with the outside world without Stahle's help and without Stahle's knowledge. Protests or requests which they might have been too afraid to make to 
his face they could now make in writing, behind his back, to his superiors who could call him to account for his actions.

Supporters of John Sutton Sr and his group, such as Mr Elmore and local Justice of the Peace, J. N. McLeod, undermined Stahle's power by breaking his monopoly over the channels of communication between the Aboriginal residents and the Board. Through such intermediaries, the Condah residents could bypass Stahle and convey their grievances directly to his superiors. When the 'Aboriginals' Narrative' was sent to Captain Page in early November 1880, he forwarded it to Stahle with a request to 'please explain'. Stahle duly explained by labelling his accusers liars, profligates and rebels. In his letter to Page of 6 November 1880, he boldly asserted "All the statements made in the "Aboriginal Narrative" are false and unfounded', but had to add lamely '(with the exception of those to which I have referred as being correct in my letter)' ${ }^{14}$ Stahle was clearly rattled. Later the same day he wrote a second letter to Page refuting the latter's remark that Mr Elmore 'seems a nice old gentleman'. Furious at Elmore's involvement, Stahle asked 'whether proceedings could not be taken against a man like Elmore for forwarding such statements to those in authority without having made any enquiry into the truth of them?' Fearing his credibility was shaky, Stahle sent Page a collection of favourable remarks culled from the Lake Condah visitors' book, together with 'a few lines from Miss Gregory [the school teacher] testifying to the correctness of my statements'. ${ }^{15}$ One wonders whether, under the circumstances, Miss Gregory could possibly have declined to corroborate Stahle's word.

\section{'Dangerous wanderers'}

The boundary between hidden and public transcripts is a zone of constant struggle. By limiting what can be said publicly (as distinct from what is publicly known or thought), dominant elites lock up much of the latent power of subordinate groups' knowledge. They can seldom entirely prevent counterhegemonic discourses from coming into being, but by keeping expressions of dissent from being freely transmitted, they can stop them spreading between subordinate groups and being translated into large-scale, coordinated political actions. The 
restrictions placed on Aboriginal people's movements under the reserve system meant that they had limited opportunities to transmit their hidden transcripts beyond their own reserve boundaries. The more cut off each reserve was both from nonAboriginal society and from other Aboriginal reserves, the narrower the social reach of the Aboriginal residents' hidden transcripts.

Yet no reserve could be hermetically sealed altogether. People wrote letters to relations and friends on other reserves, and sometimes to non-Aboriginal friends as well. ${ }^{16}$ At Lake Condah, Stahle is known to have intercepted some of these letters. Occasionally people gained permission to visit relations on other reserves, and they maintained contact with Aboriginal people who lived near but outside the reserve. Another channel of communication were the so-called 'troublemakers' who were banished periodically to distant reserves by Orders in Council. Also influential were those who slipped through the net of the reserve system altogether, and carried hidden expressions of dissatisfaction between reserves.

When hidden transcripts are transmitted for the first time between isolated cells of an oppressed group, members of that group can recognise themselves as a group for the first time. They learn the extent to which their political circumstances and living conditions are shared, and see the degree to which their feelings of anger, humiliation and so forth are held in common. Without adopting an essentialist approach to Aboriginal people or any other group, it is reasonable to suggest that those who live within the same structure or system of domination are likely to have a common body of shared experiences, patterns of behaviour, speech-habits, ideas and feelings about their circumstances. In so far as their conditions of subordination have been similar it is valid to assume there will be some family resemblance between their hidden transcripts (as well as between their public ones). ${ }^{17} \mathrm{By}$ carrying hidden transcripts between different reserve communities, itinerants could ignite a new, politically formidable sense of social cohesion among previously atomised groups. The hidden transcripts of different groups could thus coalesce and consolidate into more fully developed counter-hegemonic public transcripts that in turn supported open expressions of 
insubordination. For these reasons, Stahle and other reserve officials regarded itinerant and unconfined Aborigines as a potentially serious political threat.

One such 'dangerous wanderer' was James Scott, who arrived at Lake Condah Mission Station in early November 1880. ${ }^{18}$ At that time, the 'Aboriginals' Narrative' document had sat dormant for four months in the hands of John Sutton and his group. It is surely not coincidental that just after James Scott's arrived at Lake Condah, Sutton and his group sent their damning narrative to Stahle's boss, Captain Page at the Board. Because Scott did not live on the reserve, he may have been more willing than the permanent residents to risk airing his inflammatory views within Stahle's sight and hearing. Scott could leave the reserve at will so that, unlike the permanent residents, he did not have to bear the brunt of the superintendent's acrimony in the long term. His brazenness may well have stimulated others into showing their resentment more openly. As well as being an influential speaker, Scott may have exerted considerable political influence as an audience - an outspoken outsider in whose eyes the men may have wished to appear similarly forthright. This 'dangerous wanderer's' outspokenness may have triggered the Condah men's decision to unhide their hidden transcript, take their document out of mothballs, and make their grievances known to Captain Page.

Stahle seems not to have connected Scott's arrival at Lake Condah with the men's decision to send their damning narrative to Captain Page. However, within days of having explained his side of the 'Aboriginals' Narrative' to the Board, he wrote again to Page complaining about Scott's disruptive influence:

I am quite alarmed about the half-caste James Scott. Whenever \& wherever he sees a few men sitting together he joins them \& commences his yarns [about] what ought what could \& should be done with regard to this place \& that they should not rest until the Government would give them their rights ... It is a matter of the greatest regret to see men who have been for over two years contented happy \& cheerful go about with the same sulky \& 
discontented look as some of them have done some two years ago. ${ }^{19}$

Stahle believed (or wanted Page to believe) that that prior to Scott's arrival, the Condah men were 'contented happy \& cheerful' - hegemonically controlled, in other words. He believed (or wanted Page to believe) that Scott had caused the men's discontent, yet he half understood that there was some connection between their present 'sulky and discontented' look and the troubles of two years ago, recounted in the 'Aboriginals' Narrative'. Stahle seems oblivious to the possibility that the men had been carrying grudges from years ago, or that their cheerful countenances were masks worn to avoid aggravating him. He appears to have thought their anger and resentment had been quelled in 1878. In fact, the documentary evidence suggests the men's bitter feelings had merely gone underground and that Scott's talk, as well as introducing new information and ideas to Lake Condah, was acting as a catalyst bringing the Condah men's existing hidden transcript into public view.

On the same day as Stahle informed Page of Scott's activities, his wife, Mary Stahle, wrote to Page without her husband's knowledge, telling him how serious the unrest at Lake Condah was becoming:

Scott [is] telling the blacks how badly they are treatedand how they should not rest until their wishes are fulfilled, until they become their own masters, not to be led like children any more. ${ }^{20}$

Mary Stahle's letter covert communication with her husband's superior tells of the presence of a new Aboriginal public discourse on the reserve. James Scott was not agitating merely for additional food or tobacco rations, nor was he urging the men to repudiate Stahle for failing to live up to the ideals that allegedly validated colonial domination. He was renouncing the hegemonic public discourse of protectionism altogether. Echoing the talk of abolitionists and freedom fighters, Scott was taking the far more radical step of repudiating the very principle by which Aboriginal peoples' lives were controlled by 
anyone but themselves.

Itinerants such as Scott could potentially electrify an entire region by carrying previously isolated hidden transcripts from place to place. The Board for the Protection of Aborigines, already contending with complaints from Aboriginal residents of Coranderrk, Ramahyuck, and Ebenezer reserves, appear to have seen James Scott's activities at Lake Condah as a serious political threat. They acted swiftly to isolate him and curtail the effects of his visit. They ordered Scott to leave the reserve, and called in the police to confiscate the Aborigines' firearms. They also transferred John Sutton to Ebenezer Mission Station, threatened to expel those who had written letters of complaint and instigated regular fortnightly police visits to the station. ${ }^{21}$ Again, state authorities were drawing a firm line between what could be said publicly and what must be hidden.

\section{Women's voices}

Relations of domination and subordination exist within, as well as between, colonising and colonised groups. As a group's internal political structure shapes its external relations, so its dealings with outsiders affect the group's internal political dynamics. The early Lake Condah residents were a relatively homogenous cultural group; almost all were members of the Kerrupjmara people..$^{22}$ As time went by, however, Stahle exploited and intensified factional divisions in the community, to the point where John Sutton and his group accused the manager of treating 'the blacks like dogs while the half-castes are told to come in'.23 Over time, the make-up of the Condah community was changing as a result of sexual unions between white men and Aboriginal women. How did Aboriginal women view their political position? What kinds of public and hidden transcripts did they generate as individuals, as members of families and as constituents of the Condah community as a whole?

While Stahle clashed with Aboriginal men over rations, work certificates, and the right to control sexual conduct on the station, he also endeavoured to direct the lives of Aboriginal women in matters to do with their sexual relations, the custody of their children, and their place of abode. With 
one notable exception, the Condah women wrote to government authorities on matters pertaining to themselves and their immediate families, rather than as representatives of larger groupings. ${ }^{24}$ Some women's voices are elusive, refracted several times through the writings of other people, including Stahle, who usually insisted the women were happy and contented at Lake Condah.

While women such as Annie Rich and Margaret Green used highly mediated and meek modes of address, Maggie Mobourne was an outspoken female warrior. She detested Stahle, his family and the Condah school teacher, and, when angry, she expressed her contempt openly. From the late 1890 s onwards, Maggie Mobourne, acting both alone and with her husband Ernest Mobourne, challenged Stahle on a range of issues. ${ }^{25}$ The records show, however, that the Mobournes alternated strategically between overt and covert resistance, sometimes protesting bluntly and directly but at other times pleading abjectly or refracting their complaints through the voices of high-ranking government officials. Clearly, the Mobournes played a crucial role in an ongoing subculture of resistance, yet they adjusted their tactics as circumstances changed from one moment to the next.

In early 1900, Maggie launched three trenchant, public blasts against Stahle. After he reproved her for her husband's and children's absence from prayers, Maggie's anger boiled over and could not be hidden any more. In a letter to the Hamilton Spectator, she accused Stahle of being a treacherous hypocrite who:

doesn't practice what he preaches. He's not a fit person for the position he holds but is dragging us down to hell rather than helping us to rise. What I say here is true and I can take a solemn oath before God and before any Christian people as I have proofs for his falsehoods. We who know his ways often wonder he is not punished by the Master he professes to serve. ${ }^{26}$

Maggie also wrote two petitions, one to D. N. McLeod, MLA, Vice-Chairman of the BPA, the other to a local Justice of the Peace, Mr Duffit. The former is worth examining in detail: 
Mission Station

Lake Condah
February 27th, 1900

D.N. McLeod, Esqre. M.L.A.

and Vice Chairman

Sir

Having returned in September last to the Mission Station with the object of endeavouring to live in peace and in accordance with the rules of the Station I am sorry to inform you that Mr Stahle seems to take every opportunity to find fault with us, and it seems as if our efforts to live peacefully are of no use here because Mr Stahle seems determined to annoy us and to take every opportunity of reporting us to the Board for insubordination.

On the 18 th inst. Mr Stahle spoke in a threatening manner to me and stopped our rations, which he denies and I say that he is a liar and has always been. (See full particulars in another letter) and he doesn't treat us justly. I would ask you to get up an impartial Board of Inquiry to investigate and see fairness and justice.

I am prepared to substantiate my statements to be true and also can get the majority here as witnesses to prove that we have been living peacefully.

I am

Sir

Yours respectfully

Maggie Mobourne

(We the undersigned corroborate the statements given above)

Signatures

Ernest Mobourne

Robert Turner his X mark

Isaac McDuff $\mathrm{X}$

Thomas Willis his X mark

James Cortwine his X mark

Jenny Green her X mark

Albert White

Bella Mobourne 
Fred Carmichael

Louisa White her X mark

Edward P. Cortwine ${ }^{27}$

This petition seems at first glance like a triumphant outburst of previously silenced voices, a loud and strident protest against Aboriginal oppression. However, the politics of this document are more complex than they might initially appear. First, only a small proportion of the Condah community signed Maggie's two petitions. Eleven people (at least three of them close relatives ${ }^{28}$ added their names to the petition to $\mathrm{D}$. N. McLeod; ten signed the petition to Mr Duffit. Against these small numbers we might compare Ernest Mobourne's politely worded petition of 2 July 1907, to which no less that forty-eight people appended their names. Although Maggie's petitions said what others might have wanted to say, it appears that many of the Condah residents may still have been too afraid to join Maggie in saying the unsayable against Stahle.

The second issue complicating the politics of Maggie's petition to D. N. McLeod is that it did not begin as a petition at all, but rather as an individual letter. Powerless groups may hide not only their rebellious ideas and feelings, they may also conceal the extent to which they constitute themselves as a group. Maggie wrote the body of her petition to D.N. McLeod in the first person singular, beginning with ' $I$ am sorry to inform you that..., and ending with 'I am, Sir, Yours respectfully, Maggie Mobourne'. ${ }^{29}$ When she described the wrongs committed against 'us', she meant 'against Ernest and herself'. Initially, Maggie spoke for herself and her family, not as a spokesperson for her community. Nonetheless, as soon as she obtained wider corroboration of her charges against Stahle, her letter was effectively transformed into a petition. In contrast to other petitions, ${ }^{30}$ the signatures on Maggie's document were appended as a postscript. After her signature, a note was added, saying 'We the following corroborate the statements given above', after which eleven signatures appear. The most radical and daring aspect of Maggie's letter is perhaps not its content or vituperative tone, but the fact that it becomes a site upon which (a few) Aboriginal protestors constitute themselves momentarily as a visible political group. 
A third significant element in Maggie's petition (and her letter to the Hamilton Spectator) is that, for all her sharp criticisms of Stahle, Maggie's claims did not amount to an attack on protectionism or Christianity per se. She fired her shots at Stahle's character - his hypocrisy, his cruelty, his lies - but did not lash out against the systematically oppressive effects of colonialist ideology as institutionalised through the reserve system and the church. Strategically or otherwise, she did not denounce Christian principles but invoked them as a source of standards Stahle was failing to live up to. She did not denounce protectionism as such, but accused Stahle of failing in his duty of protective care. Her protest was that of an individual who, being persecuted by another individual, attempts to assassinate the character of her oppressor by showing how he fails to live up to his own professed standards and ideals. Maggie clearly did not pretend to consent to her own subordination, but nor did her letter and petition articulate the more radical emancipatory politics espoused by the 'dangerous wanderer' James Scott. Although Maggie's petition openly expressed feelings of anger and frustration, it neither advocated an anti-colonialist ideology, nor proposed an anti-colonial program of political action. Even so, Maggie and Ernest were banished to Lake Tyers.

The Mobournes were permitted to return to Condah in 1903, but were soon involved in conflicts with Stahle over Maggie's elopement with Dunmore widower, Henry Albert, and over Ernest's refusal to work or sit through Stahle's church services. In the midst of these conflicts, the BPA announced plans to close Lake Condah. In his best copperplate writing, Ernest penned a petition to the cabinet on behalf of elder Peter Hewitt and forty-seven other Condah signatories, requesting that the mission station not be closed down. This petition is a public transcript, a humble supplication in which 'the Aborigines residing at Lake Condah would earnestly pray the Cabinet to reconsider their decision and allow us to remain at Lake Condah'. Ernest supports his request by offering an idyllic narrative of the mission's history in which Stahle is characterised as a kind friend and benefactor: 
Our fathers ... with their loved missionary Mr Stahle whose labours have blessed and who is still with us then put their minds and hands together fencing in the whole reserve ... and have built stone and wooden cottages for our use, a fine church wherein to worship God, a Mission House for their much loved missionary... ${ }^{31}$

In contrast to Maggie's angry letter/petition of February 1900, Ernest's document is signed by forty-eight people - the whole Lake Condah community. It was safe to sign Ernest's petition, because its humble, supplicatory tone reassured government and Board authorities that they were in control. There was one rupture, however, in this communal performance of subordination: the order of petitioners' names suggests that, despite Stahle's attempts over a period of three decades to eradicate the Condah residents' 'primitive ways', the community's traditional structure of authority had not been entirely destroyed. Although Ernest Mobourne penned the petition, his name does not head the list of signatories. This honour is reserved for senior law-man and clever-man Peter Hewitt, whose name is immediately followed by the names of other senior men, below which in turn appear the names of the other residents..$^{32}$ The order of names may be read as a coded assertion of cultural and political autonomy, a sign of defiance that might not have been interpreted as such by those to whom the petition was addressed. Ernest's petition managed both to honour the Condah elders, and to conform to white epistolary decorum. The petition achieved its objective. Lake Condah was not closed down.

\section{Articulating silences}

In this account of Lake Condah Mission Station, which is based mainly on Protection Board documents in the Australian Archives (Victorian Office), I have been able to examine hidden transcripts only to the extent that they have not remained entirely hidden. This kind of archival research tries to read a silence by looking at its shadow, or its moments of breaking, in the written archive. Leela Gandhi has noted the importance of 'attending more carefully to the silence of the archive' and interrogating the 'construction of history 
as certain knowledge'. ${ }^{33}$ For me, here, it has sometimes been necessary to speculate on the basis of scant evidence, to acknowledge that archival silences can be inscrutable, and to remember that, like Stahle, I may be ventriloquising Aboriginal voices from a non-Indigenous position of power and privilege. Even with contextual knowledge, it is not always possible to determine whether absences and silences in the archive point to the presence of non-players, or tacitly express the equanimity of colonised subjects, or are the shadow cast by a hidden culture of resistance.

Elaborating Ranajit Guha's statement that 'there can be no colonialism without coercion', one might say that different (post?)colonial cultures, and indeed different regions and classes within nations, have been shaped by different varieties and blends of coercive and hegemonic control. At Lake Condah Mission Station, where civil and state apparatuses operated together, there is less evidence of hegemonic control than of realised or threatened coercion, less evidence of spontaneous consent to oppression than of feigned consent to avoid punishment. Like many other missions and reserves, Lake Condah was a place where, as Guha might have predicted, physical coercion clearly outweighed hegemonic control.

What role did hegemony play, then, in the oppression of Aboriginal people at Lake Condah and across the reserve system as a whole in Australia? Broadly speaking, I would suggest that while Aboriginal people were coerced into submission, most non-Aboriginal people were persuaded by hegemonic racist and colonialist discourses that such coercion was natural, just or a matter of necessary discipline. Until the late 1970s, Australian school children were taught that Aborigines offered no significant resistance to white settlers, and that those who lived on missions and reserves felt themselves fortunate to be protected and culturally uplifted. This hegemonic fiction of Aboriginal consent to the civilising mission was central to settler ideology. It blinded the majority of non-Aboriginal people to the devastating consequences of dispossession, cultural suppression, institutionalised violence, the breaking up of families and other 'dirty linen' of the white man's rule. In Australia, hegemonic discourses worked primarily to elicit the consent of the silent urban settler majority to the systematic 
oppression of fellow human beings. Hegemony did its work less on Aboriginal minds that on the minds of those who wanted to reap the benefits of colonialism without ever having to admit they were morally culpable or personally implicated in Aboriginal peoples' suffering. Ideas about hegemony were thus themselves hegemonic. The myth that Aboriginal people were hegemonically controlled was itself a hegemonic force that helped - and is still helping-large sections of the white Australian population see themselves as innocent 'non-players' in an ongoing process of racial oppression.

\section{Notes}

Stahle to Ogilvie, 19 June 1876, Australian Archives Victorian Office (AAV) Series B 313/1, Item 106.

In ordinary usage, a 'transcript' is a written copy, however, James C. Scott uses 'transcript' to refer to speech, writing, and non-verbal actions.

James C. Scott, Domination and the Arts of Resistance: Hidden Transcripts, Yale University Press, Newhaven, 1990, p. xii.

Ibid., p. 96.

Ibid., epigraph.

Simon During, 'Post-Colonialism', in K. K. Ruthven (ed.), Beyond the Disciplines: The New Humanities, Australian Academy of the Humanities, Canberra, 1992, p. 95 .

Ranajit Guha, Dominance Without Hegemony: History and Power in Colonial India, Harvard University Press, Cambridge, 1997, pp. xii, p. 24.

Scott, p. 18.

Ibid., p. 19.

John Sutton Jr to Captain Page, September [n.d.] 1877, AAV Series B313/1, Item 110.

Stahle to Page, 14 September 1877, AAV Series B313/1, Item 110.

Stahle to Page, 4 October 1877, AAV Series B313/1, Item 110.

Stahle to Page, 18 October 1877, AAV Series B 131/1, Item 110.

Stahle to Page, 6 November 188o, AAV Series B313/1, Item 115.

Ibid.

The precise extent of these forms of personal correspondence is unknown. Few personal letters survive in the government files, but more may have survived in private collections.

Scott, pp. 223-4.

No relation to James C. Scott of Yale.

Stahle to Page, 12 November 188o, AAV Series B313/1, Item 115.

Quoted in Jan Critchett, Untold Stories: Memories and Lives of Victorian Kooris, Melbourne University Press, Melbourne, 1999, p. 154.

Ibid., p. 154.

My thanks to Victor Briggs at the Koori Heritage Trust, Museum of Victoria, for this information.

F. Elmore for J. Sutton, W. Gorrie and T. Green to Page, July [n.d.] 1880; AAV Series B313/1, Item 115 .

4 This is not to say that the issues they addressed did not have relevance for the 
wider Condah community.

25 Ernest Mobourne was first reported to the BPA for disobedience in 1892. My main source of biographical information about Maggie and Ernest Mobourne is Jan Critchett's Untold Stories, Chapter 9.

26 Maggie Mobourne to the editor, Hamilton Spectator, (n.d.), quoted in Critchett, p. 160.

27 From facsimile copy of Maggie Mobourne to D. N. McLeod, MLA, 27 February 1900 (AAV Series B337, Item 507), in Critchett, p. 242.

28 The relatives I have been able to identify were Ernest Mobourne (Maggie's husband), Robert Turner (her father) and Bella Mobourne (her sister-in-law).

29 Italics added.

30 For example, Peter Hewitt et al. to the Hon. Members of the Cabinet, 2 July 1907 (penned by Ernest Mobourne), facsimile copy in Critchett, pp. 243-4.

31 Peter Hewitt et al. to the Hon. Members of the Cabinet, Critchett, p. 243.

32 This pattern is followed also in petitions written on Coranderrk Reserve. See Penny van Toorn, 'Authors, Scribes, and Owners: The Sociology of NineteenthCentury Aboriginal Writing on Coranderrk and Lake Condah Reserves', Continuum, vol. 13, no. 3, 1999, pp. 333-43.

33 Leela Gandhi, Postcolonial Theory, Allen \& Unwin, Sydney, 1998, p. 172. 